\title{
EFEKTYWNOŚĆ PORTFELI AKCJI ZABEZPIECZONYCH OPCJAMI INDEKSOWYMI NA GIEŁDZIE PAPIERÓW WARTOŚCIOWYCH W WARSZAWIE W LATACH 2007-2015
}

\section{WPROWADZENIE}

Jedną z metod ograniczania ryzyka inwestycji na rynku finansowym jest hedging - strategia zabezpieczająca przed niekorzystnymi dla inwestora zmianami cen instrumentu bazowego $\mathrm{w}$ transakcji zabezpieczającej. Wiąże się ona z wykorzystaniem instrumentów pochodnych. Jeżeli wielkość ekspozycji w instrumencie bazowym jest właściwie dopasowana do wielkości pozycji $\mathrm{w}$ instrumencie pochodnym (opcji, kontrakcie terminowym etc.) oraz daty ich wygaśnięcia, to zabezpieczenie takie określane jest jako hedging doskonały ${ }^{1}$. Oprócz motywu zabezpieczania portfeli akcji, derywaty wykorzystywane sa również do celów spekulacyjnych i arbitrażu². Hedging jest istotny dla przedsiębiorstw zabezpieczających, np. przepływy finansowe z działalności eksportowej, ponieważ ewentualne straty związane z niekorzystnymi zmianami cen walut obcych są wtedy rekompensowane przez zyski z derywatów ${ }^{3}$. Z tego powodu jest on często porównywany do ubezpieczenia ${ }^{4}$.

Należy podkreślić, że stosowanie instrumentów pochodnych w celu zabezpieczania wartości portfeli akcji nie jest powszechne na polskim rynku wśród osób zainteresowanych rynkiem i osób profesjonalnie zajmujących się inwestycjami (m.in. doradców inwestycyjnych, zarządzających w przedsiębiorstwach asset management i maklerów papierów wartościowych). Niski poziom zainteresowania instrumentami zabezpieczającymi wśród inwestorów indywidualnych tłumaczyć można m.in. niewystarczającym poziomem ich wiedzy z zakresu funkcjonowania tych instrumentów. Innym powodem hamującym częstsze wykorzystanie derywatów są ograniczenia prawne dotyczące niektórych podmiotów na rynku finansowym. Na przykład Otwarte Fundusze Eme-

${ }^{1}$ M. Bartkowiak, K. Echaust, Instrumenty pochodne. Wprowadzenie do inżynierii finansowej, Wyd. UE w Poznaniu, Poznań 2014, s. 52.

${ }^{2}$ K. Jajuga, Instrumenty pochodne. Anatomia sukcesu. Instytucje $i$ zasady funkcjonowania rynku kapitałowego, CEDUR, Komisja Nadzoru Finansowego, Warszawa 2009, s. 5-6.

${ }^{3}$ S. Antkiewicz, Procentowe instrumenty pochodne, w: K. Perez, U. Ziarko-Siwek, Inwestycje finansowe, CeDeWu.PL, Warszawa 2011.

${ }^{4}$ Z. Bodie, R. C. Merton, Finanse, tłum. J. Stolarek, A. Stolarek, PWE, Warszawa 2003, s. $402-403$. 
rytalne (OFE) nie mogą zabezpieczać nimi swoich portfeli. Byłoby to pożądane $\mathrm{w}$ celu ograniczenia ryzyka kursowego w przypadku inwestycji na rynkach zagranicznych, jednakże polskie regulacje prawne nie przewidywały dotychczas takiej możliwości.

Wykorzystanie derywatów pozwala uchronić inwestora przed znaczącym spadkiem wartości portfela w trakcie rynkowej bessy. Niemniej jednak w trakcie hossy na rynku instrumenty te zazwyczaj obniżają stopę zwrotu z portfela. W efekcie zmniejszona zostaje amplituda wahan jego zyskowności, dzięki czemu ryzyko inwestycji jest mniejsze. Trudne jest jednak bezpośrednie wskazanie, w jaki sposób hedging wpływa na relację stopy zwrotu i ryzyka portfeli.

Artykuł poświęcony jest problematyce instrumentów pochodnych (hedgingu) i ich wpływowi na efektywność portfeli akcji. Badanie dotyczy Giełdy Papierów Wartościowych w Warszawie i notowanych tam akcji, indeksów oraz opcji indeksowych. Badanie przeprowadzono w celu oceny zasadności wykorzystania instrumentów pochodnych w kontekście ich efektywności (rozumianej jako relacja stopy zwrotu do ryzyka portfeli).

Celem artykułu jest sprawdzenie na podstawie badania empirycznego efektywności portfeli zabezpieczonych opcjami indeksowymi. Dzięki wykorzystaniu instrumentów pochodnych w pewnych, ściśle określonych warunkach można uzyskać wyższą efektywność portfeli indeksów niż w przypadku portfeli niezabezpieczonych derywatami.

Badanie efektywności przeprowadzono dla polskiego rynku kapitałowego w latach 2007-2015. Spośród metod badawczych wykorzystano m.in. analizę porównawczą oraz analizę regresji do obliczenia wartości współczynnika beta. Efektywność portfeli zabezpieczonych opcjami indeksowymi i tych niezabezpieczonych została zmierzona wskaźnikami Sharpe’a, Treynora, Jensena, Information Ratio i Sortino.

Artykuł składa się z dwóch części. W pierwszej przedstawiono źródła, typy danych, metody wykorzystane w badaniu oraz jego etapy. W drugiej natomiast opracowane zostały wyniki i wnioski z badania. Wykonano szczegółowe obliczenia oraz przedstawiono wyniki inwestycji w portfel zabezpieczony opcjami indeksowymi.

\section{ETAPY I METODYKA BADANIA}

Analizie poddano przede wszystkim notowania giełdowe pozyskane z portalu gpwinfostrefa.pl prowadzonego przez Giełdę Papierów Wartościowych w Warszawie oraz z portalu dla inwestorów stooq.pl. Informacje na temat wysokości stóp procentowych oraz stopy wolnej od ryzyka zaczerpnięto ze strony internetowej Narodowego Banku Polskiego oraz portalu obligacjeskarbowe.pl.

Zakres czasowy badania obejmuje lata 2007-2015, które cechowała duża zmienność nastrojów inwestorów - na rynku giełdowym wystapił trend horyzontalny, okresy bessy oraz hossy. W rezultacie możliwa stała się ocena wyników portfeli w różnych warunkach rynkowych. Ich wyniki podsumowano na 
podstawie notowań giełdowych spółek oraz opcji indeksowych w kilku okresach. Z zakresu czasowego wyodrębniono 3 zasadnicze okresy badawcze:

- okres I: 2007-2009

- okres II: 2011-2012

- okres III: 2015

Biorac pod uwagę cały zakres czasowy badania, w tych podokresach wystapiły najbardziej znaczace spadki wartości indeksów na warszawskiej giełdzie. Okresy te warto było rozgraniczyć, aby sprawdzić przydatność hedgingu w skrajnych warunkach trendu spadkowego. W przypadku długiej pozycji w akcjach wchodzacych w skład indeksu WIG20 sytuacją niepożądanąbyła rynkowa bessa. Nabycie opcji indeksowych put wystawionych na indeks WIG20 miało na celu zabezpieczenie wartości portfela przed ryzykiem spadków na giełdzie. Badanie oparte na powyższych ramach czasowych odpowiada na pytanie, w jakiej mierze skuteczny jest hedging w przypadku braku sprzyjającej koniunktury rynkowej.

Od połowy 2007 r. rozpoczęły się silne spadki na światowych giełdach, spowodowane przede wszystkim informacjami o nasilającym się globalnym kryzysie finansowym. Bessa trwała aż do I kwartału 2009 r. Pozostałe kwartały 2009 i cały 2010 r. przyniosły uspokojenie na rynku, a przede wszystkim dość silny trend wzrostowy. W 2011 i 2012 r. wystapił trend spadkowy, który wywołany został głównie kryzysem zadłużenia w Unii Europejskiej oraz obawami o potencjalną niewypłacalność Grecji. Wzrost awersji do ryzyka spowodował wycofywanie kapitału z krajów zaliczanych do tzw. emerging markets, w tym z Polski, co odbiło się na niższych notowaniach na GPW. Lata 2013 i 2014 upłynęły pod znakiem trendu horyzontalnego. Rok 2015 obją ostatni okres badawczy, który charakteryzował się tym, że tak jak w latach 2011-2012 wystapił w nim m.in. okres szybkiego i silnego spadku.

Badanie składa się z 6 etapów. W etapie 1 dokonano wyboru 2 indeksów giełdowych. Pierwszy z nich - WIG - posłużył jako benchmark dla portfeli oraz do obliczenia współczynników beta. Drugi z indeksów - WIG20 został wybrany jako najbardziej reprezentatywny indeks największych i najbardziej płynnych spółek na Giełdzie Papierów Wartościowych w Warszawie.

W przypadku każdego z 3 okresów założono, że inwestor dokonuje zakupu akcji wchodzacych w skład indeksu WIG20 i dokonuje tego w takiej proporcji, w jakiej znajduja się one w indeksie. Może on też kupić jednostki funduszu Exchange Traded Fund (ETF), który ma za zadanie wiernie odwzorowywać indeks. Innymi słowy, inwestor de facto inwestuje „w indeks”. Zbycie akcji/ ETF następuje na końcu każdego z okresów.

Aby zabezpieczyć się przed niekorzystnymi zmianami kursu WIG20, w badaniu zastosowano opcje indeksowe. Opcje należą do derywatów niesymetrycznych, których profil wypłaty daje szansę na ponadprzeciętne zyski, a jednocześnie nie wystawia na wielkie ryzyko (w przypadku kupna opcji). Zdecydowanie nadaja się one lepiej do funkcji zabezpieczajacych niż derywaty symetryczne, takie jak kontrakty terminowe ${ }^{5}$ lub kontrakty forward, zawierane na rynku

${ }^{5}$ J. Hull, Kontrakty terminowe i opcje. Wprowadzenie, WIG-Press, Warszawa 1998, s. 1; R. G. Clarke, H. de Silva, S. Thorley, Fundamentals of Futures and Options (a summary), The Research Foundation of CFA Institute, 2013. 
pozagiełdowym $^{6}$. Asymetryczność w przypadku opcji jest cechą często wykorzystywaną również przez eksporterów, dzięki czemu mają oni możliwość zabezpieczania i jednoczesnego czerpania zysków z działalności operacyjnej ${ }^{7}$. Przepływy finansowe (rozliczenie opcji w dniu wygaśnięcia) z tytułu posiadania opcji miały pokrywać w przeważającej części ubytek wartości długiej pozycji $\mathrm{w}$ indeksach i akcjach. W badaniu nabywano po 1 opcji sprzedaży put do portfela. Opcje te należą do najczęściej wykorzystywanych instrumentów zabezpieczajacych wartość portfela. Instrumentem bazowym wszystkich opcji notowanych na GPW jest WIG20. Sa one wystandaryzowane i wygasają w trzeci piątek każdego miesiąca. Gdy ceny akcji spadaja, opcja put wystawiona na indeks może w znacznej części zrekompensować poniesione straty. Zysk nabywcy opcji put jest potencjalnie nieograniczony (lub ograniczony spadkiem ceny aż do zera), a zysk wystawcy jest ograniczony do wysokości pozyskanej premii ${ }^{8}$. Taka strategia nosi nazwę portfolio insurance ${ }^{9}$. W efekcie całkowite ryzyko portfela zabezpieczonego ulega obniżeniu. Potencjalny zwrot na inwestycji jest natomiast mniej zmienny. Powyższe argumenty wskazuja, że wykorzystanie opcji indeksowych może pozytywnie wpływać na efektywność portfeli. Uznano, że opcje ze względu na asymetryczny profil wypłaty bardziej niż inne derywaty nadają się do zabezpieczenia portfeli akcji. Zapewniają one podstawową ochronę przed ryzykiem, a jednocześnie nie pozbawiają inwestora szansy na duże zyski, jeśli ceny aktywa bazowego zmienią się w pożądanym kierunku.

W związku z powyższym sformułowano hipotezę badawcza, stwierdzająca że portfele spółek zabezpieczone derywatami są bardziej efektywne niż portfele niezabezpieczone (indeksy giełdowe).

Jako stopę wolną od ryzyka zastosowano stałą stopę oprocentowania dwuletnich obligacji skarbowych emitowanych w poszczególnych latach. Skład indeksu WIG20 posłużył do porównań efektywności portfela zabezpieczonego opcjami i niezabezpieczonego. W etapie 2 zebrano dane odnośnie do notowań indeksów oraz opcji.

W etapie 3 do portfela indeksu WIG20 dołaczono opcje indeksowe sprzedaży (put). Były one nabywane w każdym z 4 miesięcy kończacych kwartały: w marcu, czerwcu, wrześniu i grudniu. Okres od zakupu opcji aż do wygaśnięcia obejmował zatem zawsze 3 miesiące. $\mathrm{W}$ badaniu przyjęto, że opcje były kupowane w dniu po wygaśnięciu dotychczasowej ostatniej serii. Po wygaśnięciu opcji put, na następnej sesji nabywana była kolejna opcja put z najbliższym terminem wykonania. Obecność w portfelu instrumentów udziałowych i derywatów jest połączeniem instrumentów rynku kasowego i terminowego ${ }^{10}$.

${ }^{6}$ A. Sopoćko, Rynkowe instrumenty finansowe, WN PWN, Warszawa 2005, s. 147-150.

${ }^{7}$ W. Gontarski, Polskie toksyczne opcje walutowe, „Współczesna Ekonomia” 3, 2009, nr 2(10), s. 37-47; W. Gontarski, Toksyczne opcje walutowe na przyktadzie polskich opcji walutowych, Wydawnictwo Zrzeszenia Prawników Polskich, Warszawa 2009.

${ }^{8}$ D. Ford, Opcje giełdowe. Metody i strategie. Przewodnik inwestora, Liber, Warszawa 1997, s. $7-12$.

${ }^{9}$ F. K. Reilly, K. C. Brown, Analiza inwestycji i zarzadzanie portfelem I, II, tłum. A. Nowak et al., PWE, Warszawa 2001, s. 488-489.

${ }^{10}$ E. Gruszczyńska-Brożbar, Rynek finansowy państw strefy euro, w: W. Przybylska-Kapuścińska (red.), Rynek papierów wartościowych strefy euro, Oficyna Wolters Kluwer Business, Kraków 2007, s. 29. 


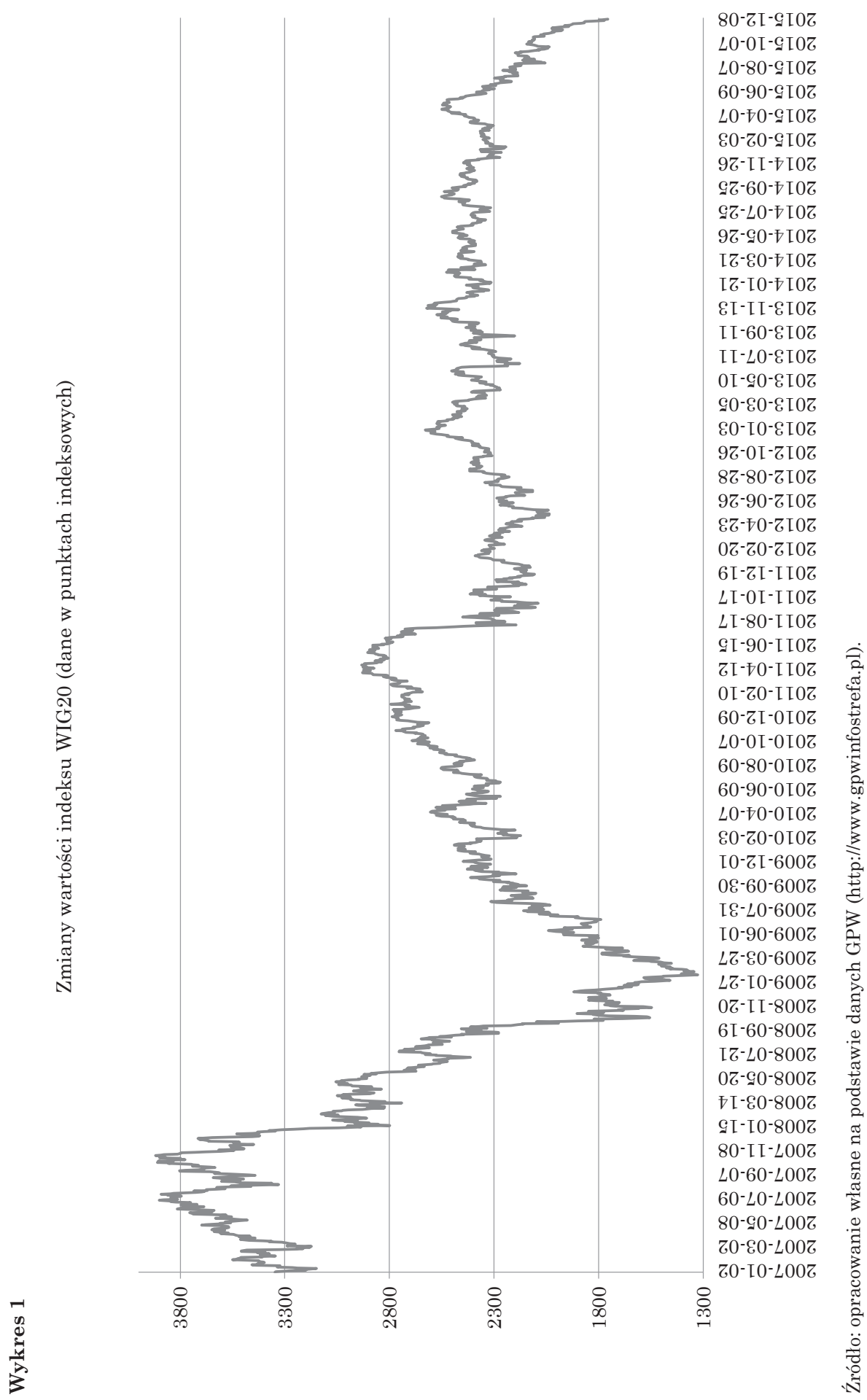




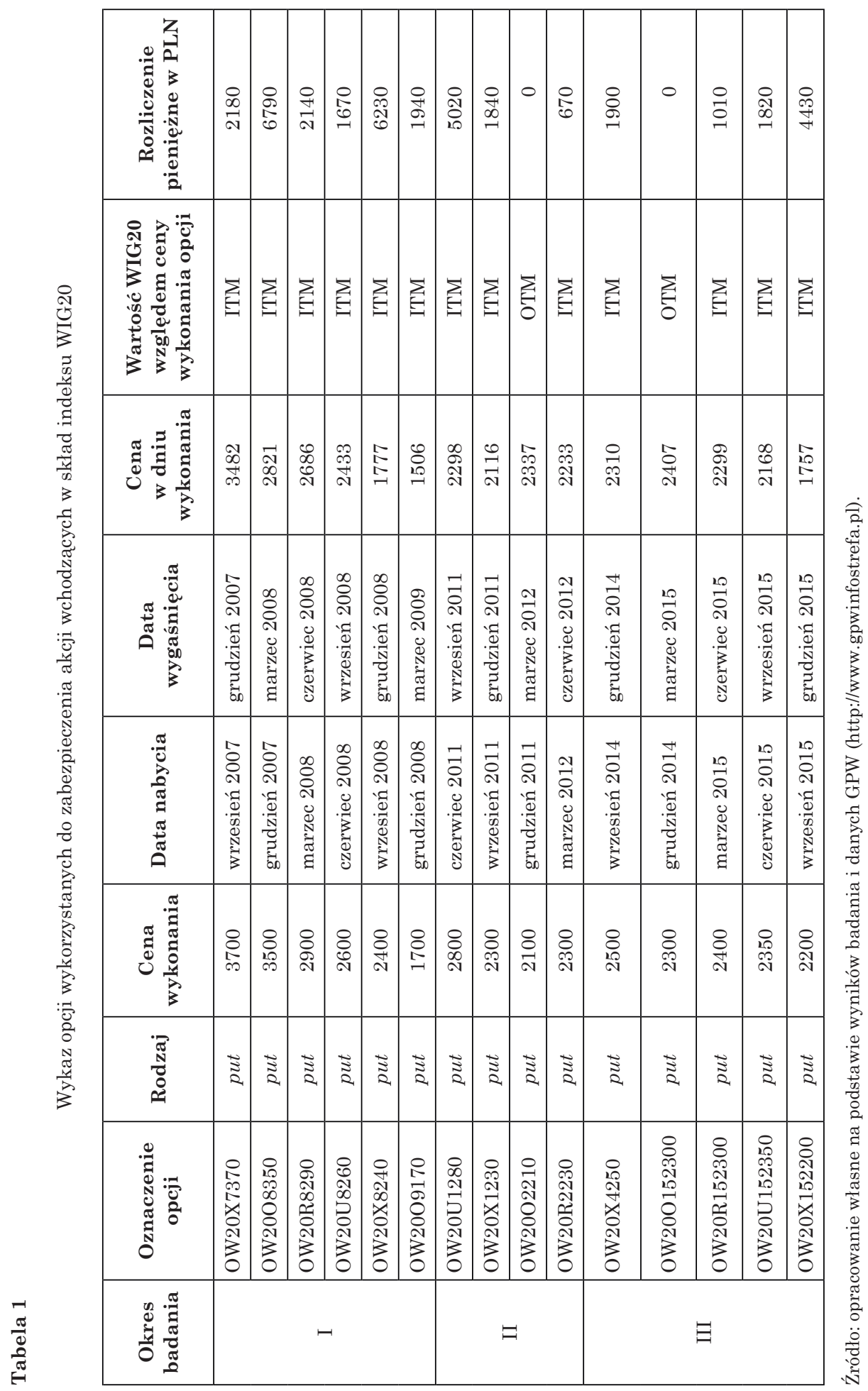


Opcje miesięczne (tj. takie, których termin wygaśnięcia nie przekracza 30 dni) zostały wprowadzone dopiero $\mathrm{w}$ sierpniu $2014 \mathrm{r}$. ${ }^{11}$ Wcześniej oferowano na GPW tylko 4-kwartalne terminy wygaśnięcia. Aby zapewnić porównywalność wyników we wszystkich 3 okresach badania, zdecydowano się w 2015 r. dalej używać opcji kwartalnych. W tabeli 1 znajduje się wykaz wszystkich wykorzystanych opcji w 3 okresach badawczych. W sumie zakupiono 15 opcji put z różnymi terminami wygaśnięcia i cenami wykonania. Następnie obliczone zostały stopy zwrotu i ryzyko (odchylenie standardowe) portfeli zabezpieczonych i niezabezpieczonych. Kalkulację przeprowadzono osobno dla wszystkich 3 okresów. Stanowiło to etap 4 obliczeń. Miary te obliczono również dla indeksu WIG, aby zapewnić porównywalność wyników portfeli do benchmarku w tym samym czasie.

\section{Tabela 2}

Mierniki efektywności obliczone w badaniu

\begin{tabular}{|l|c|c|}
\hline \multicolumn{1}{|c|}{ Miernik efektywności } & Wzór & Wzór zmodyfikowany \\
\hline wskaźnik Sharpe'a & $S_{h}=\frac{R_{i}-R_{f}}{S_{i}}$ & $S_{h}=\frac{\left|R_{i}-R_{f}\right|}{\frac{1}{s_{i}}}$ \\
\hline wskaźnik Treynora & $T_{i}=\frac{R_{i}-R_{f}}{\beta_{i}}$ & $T_{i}=\frac{\left|R_{i}-R_{f}\right|}{\frac{1}{\beta_{i}}}$ \\
\hline alfa Jensena & $\mathrm{a}=\left(\mathrm{R}_{\mathrm{i}}-\mathrm{R}_{\mathrm{f}}\right)-\beta_{\mathrm{i}} \times\left(\mathrm{R}_{\mathrm{m}}-\mathrm{R}_{\mathrm{f}}\right)$ & $\mathrm{a}=\left(\mathrm{R}_{\mathrm{i}}-\mathrm{R}_{\mathrm{f}}\right)-\beta_{\mathrm{i}} \times\left(\mathrm{R}_{\mathrm{m}}-\mathrm{R}_{\mathrm{f}}\right)$ \\
\hline wskaźnik Information Ratio & $I R=\frac{R_{e x}}{T E}$ & $I R=\frac{R_{e x}}{T E}$ \\
\hline wskaźnik Sortino & $S O R=\frac{R_{i}-M A R_{i}}{d d_{i}}$ & $S O R=\frac{\left|R_{i}-M A R_{i}\right|}{\frac{1}{d d_{i}}}$ \\
\hline
\end{tabular}

$\mathrm{R}_{\mathrm{i}}$ - średnia dzienna stopa zwrotu portfela; $\mathrm{R}_{\mathrm{f}}$ - średnia stopa zwrotu wolna od ryzyka; $\mathrm{S}_{\mathrm{i}}$ - odchylenie standardowe dziennej stopy zwrotu w badanym okresie; $B$ - miara ryzyka systematycznego portfela; $\mathrm{R}_{\mathrm{m}}$ - oczekiwana rynkowa stopa zwrotu (np. stopa zwrotu WIG); MAR - minimalna akceptowalna stopa

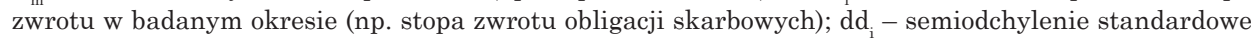
portfela; $\mathrm{R}_{\mathrm{ex}}$ - nadwyżkowa stopa zwrotu portfela; TE - tracking error - odchylenie standardowe nadwyżkowej stopy zwrotu

Źródło: opracowanie własne na podstawie: E. J. Elton, M. J. Gruber, Nowoczesna teoria portfelowa i analiza papierów wartościowych, tłum. G. Łętocha et al., WIG Press, Warszawa 1998; H. Mayo, Investments. An Introduction, South Western Cengage Learning, Mason, USA, 2011; K. Perez, J. Truszkowski, Portfel inwestycyjny, Wyd. UE w Poznaniu, Poznań 2011; E. F. Brigham, J. Houston, Fundamentals of Financial Management, 10th ed., Thomson South-western, Natorp Boulevard 2004; F. Sortino, The Sortino Framework for Constructing Portfolios, Focusing on Desired Target Return to Optimize Upside Potential Relative to Downside Risk, Elsevier Inc., USA, 2010; M. Ridley, How to Invest in Hedge Funds, Kogan Page, London, UK, 2004; F. K. Reilly, K. C. Brown, op. cit.

${ }^{11}$ Stowarzyszenie Inwestorów Indywidualnych 2015 [SII]; http://www.sii.org.pl/7905/aktualnosci/newsroom/czym-sa-nowo-wprowadzane-opcje-miesieczne.html [dostęp: 14.12.2015]. 
W etapie 5 obliczono efektywność portfeli za pomocą wskaźników wyszczególnionych w tabeli 3 . W tym celu posłużono się formułami zastosowanymi do obliczania efektywności składów indeksów giełdowych ${ }^{12}$. Podstawowe formuły, za pomocą których obliczane są mierniki efektywności, zmodyfikowano w celu uzyskania porównywalnych wyników. Należy zauważyć, że ze względu na giełdową bessę panującą w wymienionych 3 okresach wskaźniki przyjmowałyby w większości wartości ujemne. Ich interpretacja byłaby wtedy utrudniona. Formuły przekształcono w taki sposób, aby mimo ujemnych stóp zwrotu na rynku właściwie wskazywały różnice w efektywności portfeli. Dzięki zmodyfikowanym formułom wskaźniki Sharpe'a, Treynora, Information ratio i Sortino przyjmowały dodatnie wartości. Im wartość zmodyfikowanego wskaźnika była niższa (bliższa zeru), tym wyższa efektywność danego portfela (indeksu). Zmiana formuły pociagnęła za sobą zmianę interpretacji, ponieważ według standardowych wzorów wartości wskaźników uznaje się za tym lepsze (bardziej efektywne), im są one wyższe.

Aby zweryfikować wpływ hedgingu na ich efektywność w etapie 6, porównano wartości wskaźników portfeli zabezpieczonych opcjami i portfeli niezabezpieczonych opcjami. Miały one parami bardzo podobne składy, różniły się wyłącznie uwzględnieniem (w przypadku portfeli zabezpieczonych) opcji na WIG20. Portfele zabezpieczone obejmowały zawsze 1 opcję indeksowa put. Wielkość pozycji w opcjach została dopasowana do wartości portfela w taki sposób, aby zapewniać właściwe zabezpieczenie, tj. aby potencjalne straty z akcji były pokrywane dodatnimi przepływami finansowymi z opcji (rozliczenie w dniu wygasania opcji). Wartość portfela niezabezpieczonego na początku okresu odpowiadała dziesięciokrotności wartości indeksu WIG20. Natomiast wartość portfela zabezpieczonego została powiększona dodatkowo o wartość 1 opcji put. Dziesięciokrotność wartości indeksu WIG20 jest dopasowana do wielkości pozycji w opcji. Powyższe wagi instrumentów w portfelu zabezpieczonym (10-krotność wartości WIG20 i 1 opcja) były stałe w próbie. Portfel niezabezpieczony bez względu na okres badawczy ma wartość 10-krotności indeksu WIG20. Wartość indeksu WIG20, która podlegała w okresie badawczym znacznym wahaniom, nie jest kluczowa dla wyboru wag do portfela. Najważniejsza jest wartość mnożnika opcji, dzięki któremu zysk z opcji idealnie pokrywa potencjalna stratę z portfela indeksu. Opcje notowane na GPW charakteryzują się mnożnikiem wynoszącym 10, w związku z tym wzrost (spadek) wartości indeksu o 1 pkt powoduje wzrost (spadek) wartości portfela $10 \mathrm{PLN}^{13}$. W następstwie wykorzystania dźwigni finansowej (lewara) zyski lub straty z opcji są wielokrotnie wyższe, niż wynikałoby to jedynie ze zmiany cen

${ }^{12}$ M. Flotyński, The efficiency of stock market indices in Poland - the empirical evidence, w T. Dudycz, G. Osbert-Pociecha, B. Brycz (red.), Efektywność - rozważania nad istota i pomiarem, Prace Naukowe Uniwersytetu Ekonomicznego (AE) we Wrocławiu, nr 386, Wrocław 2015, s. $27-50$.

${ }^{13}$ K. Mejszutowicz, Podstawy inwestowania $w$ kontrakty terminowe $i$ opcje, Giełda Papierów Wartościowych w Warszawie SA, Warszawa 2013, s. 81. 
instrumentu bazowego ${ }^{14}$. Natomiast 1 pkt spadku wartości indeksu spowoduje dodatnie rozliczenie w wysokości 10 PLN w dniu wygaśnięcia opcji put. Zrekompensuje ono poniesioną stratę z tytułu pozycji długiej w akcjach. Do portfela wybierane były opcje, których cena wykonania różniła się możliwie jak najmniej od aktualnego poziomu indeksu WIG20. Były to zatem opcje spełniajace warunek ATM (at the money). Cena wykonania idealnie dopasowanej opcji ATM jest tożsama z ceną instrumentu bazowego ${ }^{15}$. Warto nadmienić, że opcje call byłyby w tej sytuacji nieadekwatne i nie spełniałyby właściwie funkcji zabezpieczającej (portfele akcji powinny być zabezpieczane przed spadkami, a taka funkcję spełniają opcje put). Opcje call przyniosłyby zysk, gdyby WIG20 wzrósł. Gdyby jego wartość spadła, opcje przyniosłyby stratę równa wysokości zapłaconej premii opcyjnej.

Należy zwrócić uwagę na fakt, że w badaniu pominięto wszelkie koszty transakcyjne, które pogarszałyby wyniki portfeli. Warto również zauważyć, że portfel niezabezpieczony składał się wyłącznie z akcji (wg proporcji w indeksie WIG20). Jedyną różnicą w składzie portfeli zabezpieczonych i niezabezpieczonych było zatem uwzględnienie opcji indeksowej w portfelu zabezpieczonym. Gdy opcje put wygasały w pieniądzu (ITM - in the money), były wykonywane i do portfela przypisywana została dodatnia kwota rozliczenia. Gdy opcja wygasała poza pieniądzem (OTM - out of the money), wtedy nie była ona wykonywana, a strata równa była premii zapłaconej w momencie nabycia opcji.

\section{REZULTATY BADANIA}

W tabeli 3 przedstawiono statystyki indeksu WIG, WIG20 i portfeli oraz wartości mierników efektywności. Dla poszczególnych okresów obliczono: stopę zwrotu (przy założeniu inwestycji na początku okresu i sprzedaży na jego końcu), średnią dzienna stopę zwrotu, odchylenie standardowe, współczynnik beta, korelację portfela i indeksu WIG20 z indeksem WIG. Uwzględniono również zmodyfikowane mierniki: wskaźnik Sharpe’a, wskaźnik Treynora, Information ratio, wskaźnik (alfa) Jensena i wskaźnik Sortino. Znamienne jest, że portfel zabezpieczony opcją we wszystkich 3 okresach zanotował wyższą stopę zwrotu (chociaż ciagle jeszcze ujemna) niż indeks WIG20 i WIG. Okres I charakteryzował się szczególnie drastycznym spadkiem wartości indeksów WIG i WIG20 - odpowiednio ok. 61\% i $59 \%$, przy spadku wartości portfela z opcją o $28 \%$. Warto wspomnieć, że w porównaniu z indeksem WIG i WIG20, portfel wykorzystujący instrumenty pochodne zanotował w każdym z badanych okresów wyższą stopę zwrotu oraz niższe odchylenie standardowe. Jest to zatem oczywiste, że dla

${ }^{14}$ J. Czekaj (red.), Rynki, instrumenty $i$ instytucje finansowe, WN PWN, Warszawa 2008, s. $450-452$.

${ }^{15}$ K. Jajuga, T. Jajuga, Inwestycje: instrumenty finansowe, ryzyko finansowe, inżynieria finansowa, wyd. 2 uaktualnione, PWN, Warszawa 2006, s. 182. 
portfela z opcją stosunek zysku do ryzyka musi być korzystniejszy niż dla indeksów. Niemniej jednak trzeba zauważyć, że instrumenty pochodne nie zagwarantowały zysku. W tym przypadku wartość portfela również spadła, choć najmniej w badanej grupie. Ujemne stopy zwrotu są z pewnością zła informacją dla inwestora. Jednak warto mieć na uwadze to, że na rynku, na którym panuje wyraźny trend spadkowy, trudno jest osiagać dodatnie stopy zwrotu. Zazwyczaj w takich przypadkach jako sukces traktuje się ujemną stopę zwrotu, będącą znacznie powyżej stopy zwrotu z szerokiego rynku (WIG). Tym samym rezultaty zastosowania derywatów były zachęcające. Dla przykładu, w okresie III portfel stracił ok. 8,7\%, podczas gdy indeks WIG i WIG20 straciły odpowiednio $20,5 \%$ i $30,8 \%$. Była to tylko niewielka korekta wartości w przeciwieństwie do wyraźnie przecenionych indeksów.

Bardzo podobna sytuacja wystapiła w przypadku odchylenia standardowego. Było ono najniższe w każdym okresie dla portfela zabezpieczonego. Tym samym wartość portfela z opcją była najmniej zmienna w podanych okresach, dzięki czemu inwestycja była najmniej ryzykowna. Kolejna kolumna zawiera wartości innej miary ryzyka. Współczynnik beta obliczony na podstawie klasycznej metody najmniejszych kwadratów (KMNK) wyraźnie ukazuje charakterystykę zachowania indeksu i portfela $\mathrm{z}$ instrumentami pochodnymi. Beta jako miara ryzyka systematycznego wskazuje do jakiego stopnia portfel jest podatny na zmiany wartości benchmarku (indeksu WIG). Portfel zabezpieczony był bardziej odporny na nagłe zmiany wartości szerokiego rynku. Na rynku z trendem wzrostowym taki portfel zyskuje mniej, ale również traci zdecydowanie mniej od benchmarku na rynku spadkowym. Należy zauważyć, że dla indeksu WIG20 jego wartości oscyluja wokół 1,1 w każdym z okresów, co powoduje, że może być on postrzegany jako „agresywny” portfel aktywów (wartość beta powyżej 1). Jednocześnie wartości współczynnika beta portfela z opcją znajdują się w przedziale $<0,32 ; 0,49>$ co wskazuje na „defensywna” cechę tego portfela (wartość beta poniżej 1). Ponadto współczynnik ten świadczy o niższym ryzyku inwestycji w portfel zabezpieczany derywatami. Współczynnik korelacji Pearsona przyjmował bardzo wysokie wartości w okresie I w przypadku obu portfeli. Świadczyło to o tym, że zmiany wartości WIG, WIG20 i portfela z opcja zachodziły „w tym samym kierunku”. Wraz ze wzrostem wartości WIG, rosła również wartość WIG20 i portfela. Przy spadku wartości WIG pozostałe instrumenty również traciły na wartości. W okresach II i III zachodziła wysoka korelacja pomiędzy indeksami WIG20 i WIG, natomiast była ona zdecydowanie niższa dla portfela i WIG.

Kolejne 5 kolumn w tabeli przedstawia wyniki obliczeń dla mierników efektywności. Zdecydowana większość z nich wskazuje na wyższą efektywność portfela zabezpieczonego. Tak dobre wyniki współczynników efektywności portfela z opcją nie powinny dziwić, ponieważ bazują one na stopie zwrotu oraz ryzyku portfela. Stopa zwrotu portfela z opcją była w każdym przypadku wyższa od benchmarków, a ryzyko mierzone odchyleniem standardowym i współczynnikiem beta było niższe w każdym okresie. Wartości 


\begin{tabular}{|c|c|c|c|c|c|c|c|c|c|c|}
\hline \multirow{12}{*}{ 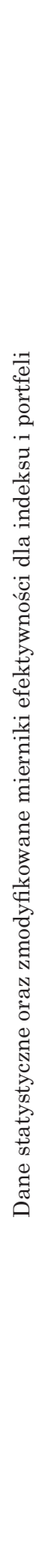 } & 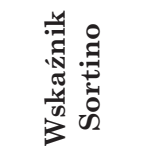 & $\begin{array}{l}\infty \\
\ddot{1} \\
0 \\
8 \\
8 \\
0 \\
0\end{array}$ & $\begin{array}{l}8 \\
\infty \\
8 \\
8 \\
8 \\
8 \\
0 \\
0\end{array}$ & $\begin{array}{l}0 \\
1 \\
8 \\
8 \\
8 \\
8 \\
0 \\
0\end{array}$ & $\begin{array}{l}\infty \\
0 \\
0 \\
0 \\
8 \\
8 \\
0 \\
0\end{array}$ & $\begin{array}{l}8 \\
0 \\
0 \\
8 \\
0 \\
0 \\
0\end{array}$ & $\begin{array}{l}\infty \\
\infty \\
0 \\
8 \\
8 \\
8 \\
0 \\
0\end{array}$ & $\begin{array}{l}10 \\
0 \\
0 \\
8 \\
8 \\
8 \\
0 \\
0\end{array}$ & 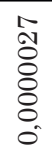 & $\begin{array}{l}\overrightarrow{1} \\
\stackrel{8}{8} \\
8 \\
0 \\
0\end{array}$ \\
\hline & 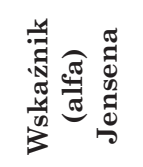 & & & & $\begin{array}{l}\text { N } \\
\text { ô. } \\
\text { Oे } \\
8 \\
0 \\
0 \\
1\end{array}$ & 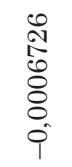 & 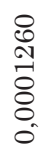 & 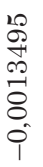 & $\begin{array}{l}0 \\
1 \\
\infty \\
10 \\
8 \\
0 \\
0 \\
1\end{array}$ & 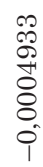 \\
\hline & 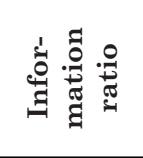 & & & & 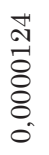 & $\begin{array}{l}0 \\
\varnothing \\
8 \\
0 \\
0 \\
0 \\
0\end{array}$ & $\begin{array}{l}\infty \\
\text { ô } \\
8 \\
0 \\
8 \\
0 \\
0\end{array}$ & $\begin{array}{l}10 \\
0 \\
-1 \\
8 \\
8 \\
0 \\
0\end{array}$ & $\begin{array}{l}8 \\
0 \\
8 \\
8 \\
8 \\
0 \\
0\end{array}$ & $\begin{array}{l}\text { के } \\
\text { ठे } \\
\vdots \\
\vdots \\
0\end{array}$ \\
\hline & 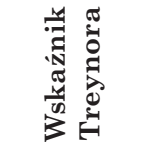 & & & & 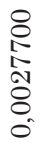 & $\begin{array}{l}7+1 \\
18 \\
0 \\
0 \\
0 \\
0 \\
0\end{array}$ & 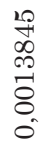 & $\begin{array}{l}\text { ㄱ } \\
\infty \\
\infty \\
0 \\
8 \\
0 \\
0\end{array}$ & 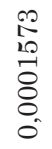 & 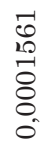 \\
\hline & 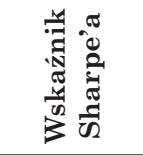 & $\begin{array}{l}8 \\
\infty \\
+ \\
8 \\
8 \\
8 \\
0 \\
0\end{array}$ & 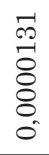 & $\begin{array}{l}1 \\
8 \\
8 \\
8 \\
8 \\
0 \\
0\end{array}$ & $\begin{array}{l}0 \\
\text { ô } \\
i \\
0 \\
0 \\
0 \\
0 \\
0\end{array}$ & $\begin{array}{l}8 \\
0 \\
0 \\
8 \\
8 \\
0 \\
0\end{array}$ & 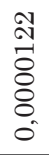 & $\begin{array}{l}\text { ㅇ } \\
\text { - } \\
8 \\
8 \\
8 \\
0 \\
0\end{array}$ & $\begin{array}{l}10 \\
\text { \& } \\
8 \\
8 \\
8 \\
0 \\
0\end{array}$ & $\begin{array}{l}\text { ते } \\
\text { ठे } \\
0 \\
0 \\
0 \\
0\end{array}$ \\
\hline & 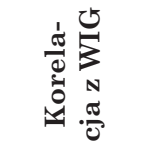 & & & & 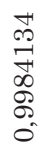 & $\begin{array}{l}10 \\
10 \\
0 \\
0 \\
0 \\
0 \\
0 \\
0\end{array}$ & $\begin{array}{l}\text { 동 } \\
\text { + } \\
\text { Nै } \\
\text { oे } \\
0\end{array}$ & $\begin{array}{l}11 \\
10 \\
\infty \\
\infty \\
\infty \\
\infty \\
0 \\
0\end{array}$ & $\begin{array}{l}8 \\
\infty \\
0 \\
0 \\
0 \\
0 \\
0\end{array}$ & 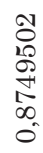 \\
\hline & 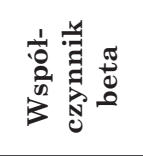 & & & & 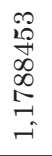 & 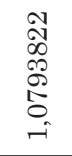 & $\begin{array}{l}\infty \\
\infty \\
+ \\
\infty \\
\infty \\
10 \\
\stackrel{-1}{-1}\end{array}$ & $\begin{array}{l}\text { N } \\
\infty \\
\infty \\
\infty \\
\infty \\
\infty \\
\infty \\
0\end{array}$ & 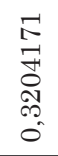 & 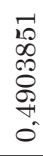 \\
\hline & 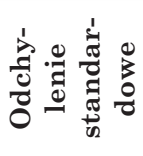 & $\begin{array}{l}5 \\
0 \\
0 \\
\infty \\
0 \\
0 \\
0\end{array}$ & 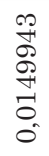 & $\begin{array}{l}0 \\
0 \\
0 \\
0 \\
0 \\
8 \\
0 \\
0\end{array}$ & \begin{tabular}{l}
$\mathscr{y}$ \\
0 \\
$\infty$ \\
\multirow{1}{*}{} \\
Nै \\
0 \\
0
\end{tabular} & $\begin{array}{l}0 \\
0 \\
0 \\
0 \\
0 \\
0 \\
0 \\
0\end{array}$ & $\begin{array}{l}\text { \% } \\
\text { O⿱ } \\
\text { Oै } \\
0 \\
0 \\
0 \\
0\end{array}$ & 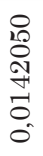 & 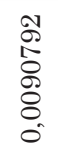 & 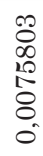 \\
\hline & 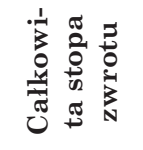 & $\begin{array}{l}\text { ลें } \\
\text { बे } \\
0 \\
0\end{array}$ & $\begin{array}{l}\stackrel{0}{\infty} \\
\stackrel{+}{+} \\
\stackrel{1}{+} \\
+1\end{array}$ & $\begin{array}{l}\text { مे } \\
\text { î } \\
\text { คิ } \\
\text { 1े }\end{array}$ & 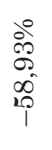 & $\begin{array}{l}\text { @े } \\
\text { †े } \\
\text { ลิ } \\
\text { 1 }\end{array}$ & $\begin{array}{l}0_{0}^{0} \\
\infty \\
\infty \\
\infty \\
\infty\end{array}$ & 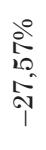 & $\begin{array}{l}0 \\
\stackrel{0}{7} \\
\stackrel{1}{0} \\
\stackrel{1}{1}\end{array}$ & $\begin{array}{l}\stackrel{\circ}{\circ} \\
\stackrel{0}{\circ}\end{array}$ \\
\hline & 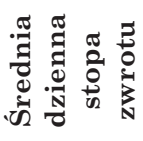 & $\begin{array}{l}\stackrel{\circ}{\circ} \\
\stackrel{+}{2} \\
\stackrel{1}{0} \\
\text { i }\end{array}$ & $\begin{array}{l}\stackrel{\circ}{N} \\
\text { Iิ } \\
\text { i }\end{array}$ & $\begin{array}{l}80 \\
80 \\
0 \\
0 \\
1\end{array}$ & $\begin{array}{l}\text { oे } \\
\stackrel{9}{N} \\
\hat{N} \\
\hat{1}\end{array}$ & $\begin{array}{l}0 \\
\text { oे } \\
0 \\
0 \\
0\end{array}$ & $\begin{array}{l}\stackrel{\circ}{\circ} \\
\stackrel{-}{0} \\
\stackrel{0}{1}\end{array}$ & $\begin{array}{l}80 \\
0 \\
0 \\
0 \\
0 \\
1\end{array}$ & $\begin{array}{l}\stackrel{0}{0} \\
\text { के } \\
0 \\
0 \\
1\end{array}$ & 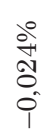 \\
\hline & $\begin{array}{l}0 \\
0 \\
\frac{\pi}{\tilde{H}} \\
0\end{array}$ & $\varpi$ & $\Xi$ & ヨ & 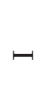 & 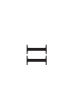 & $\Xi$ & $\mapsto$ & $\boxminus$ & 目 \\
\hline & 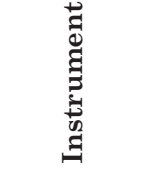 & & $\underbrace{J}_{3}$ & & & 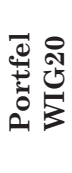 & & & ฐ & \\
\hline
\end{tabular}


współczynnika beta, korelacji, wskaźnika Treynora, alfy Jensena oraz Information ratio nie obliczano dla indeksu WIG ze względu na to, że stanowił on benchmark dla portfela zabezpieczonego i indeksu WIG20. Gdyby wartości te miałyby być obliczone, należałoby znaleźć dla WIG-u inny benchmark. Zazwyczaj wskazuje się, że im wyższa jest alfa Jensena, tym bardziej efektywny jest portfel. Portfel zabezpieczony miał wyższą wartość alfy niż WIG20 dla okresu I i II, czyli w 2/3 okresów badawczych. Wskaźniki Sharpe'a, Treynora, Information Ratio i Sortino dla portfela zabezpieczonego przyjmuja niższe wartości niż dla indeksów WIG i WIG20. W nawiązaniu do zmodyfikowanych formuł, według których są liczone, wskazuje to na wyższą efektywność portfela zabezpieczonego instrumentami pochodnymi. Wskaźnik Sortino uwzględniający semiodchylenie standardowe (odchylenie standardowe wyłącznie ujemnych stóp zwrotu) potwierdza przewagę efektywności portfela $\mathrm{z}$ opcją nad indeksami.

Wykresy 2-4 prezentują zmiany wartości portfeli zabezpieczonych i niezabezpieczonych w poszczególnych okresach. W każdym z przypadków oba portfele straciły na wartości, co związane było z silnymi spadkami na szerokim rynku. Pomiar stopy zwrotu dokonany był przy założeniu dokonania zakupu akcji w proporcji wyznaczanej przez indeks na początku okresu, dostosowywania składu portfela do zmian w indeksie i sprzedaży aktywów na koniec okresu. Niemniej jednak warto zauważyć, że w każdym z okresów portfele $\mathrm{z}$ instrumentami pochodnymi traciły na wartości znacznie mniej niż indeksy.

W okresie I portfel zabezpieczony stracił ok. 30\% wartości, podczas gdy portfel niezabezpieczony utracił ok. 60\%. W okresie II spadek wartości portfeli nie był aż tak silny. Utraciły one odpowiednio 11\% i $21 \%$. W okresie III portfele utraciły odpowiednio ok. 10\% i ok. 30\%. W drugiej połowie 2015 r. użyteczność zastosowania opcji indeksowych była szczególnie widoczna. W tym czasie indeks WIG20 był w silnym trendzie spadkowym, podczas gdy trend spadkowy wartości portfela zabezpieczonego był łagodny i nie nastapił żaden silny, kilkudniowy spadek. W pozostałych okresach również widoczna jest ta zależność. Jednocześnie warto zwrócić uwagę na fakt, że opcje indeksowe chroniły wartość portfela w szczególności w okresach silnego spadku wartości indeksu - wtedy bardzo wyraźna staje się różnica pomiędzy wartościami obu portfeli. Na wykresach wyraźnie pokazano, że linia portfela zabezpieczonego opada znacznie bardziej łagodnie niż linia indeksu WIG20. Jest ona „wygładzona”, a amplituda wartości portfela jest zdecydowanie niższa. Opcje indeksowe stanowiły najbardziej efektywna ochronę wartości portfela $\mathrm{w}$ trakcie silnych spadków cen na giełdzie. Takie okresy sa widoczne na wykresach $2-4$. W trakcie trendu wzrostowego natomiast były mniej użyteczne i powodowały wyhamowanie wzrostu wartości portfela. 


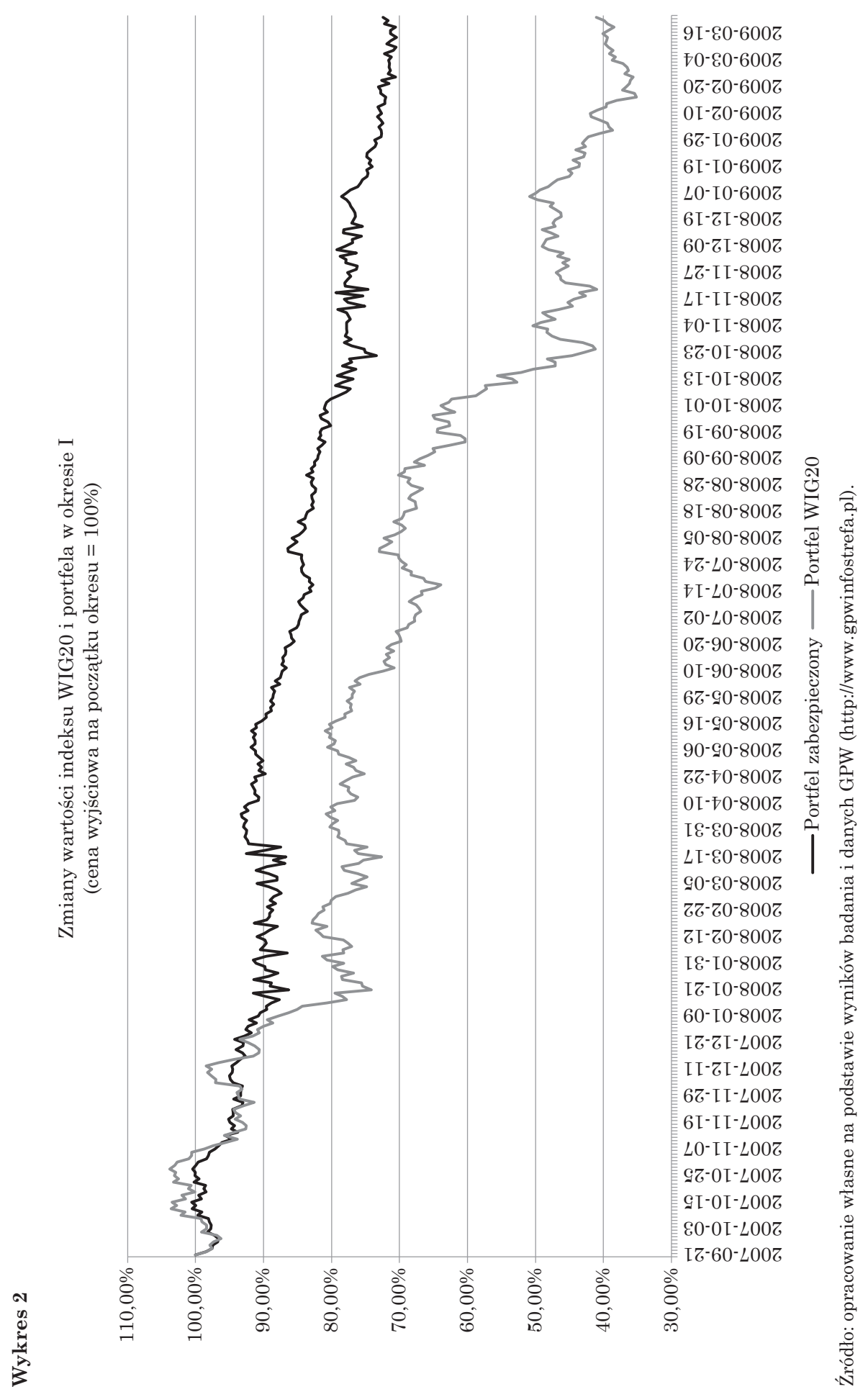




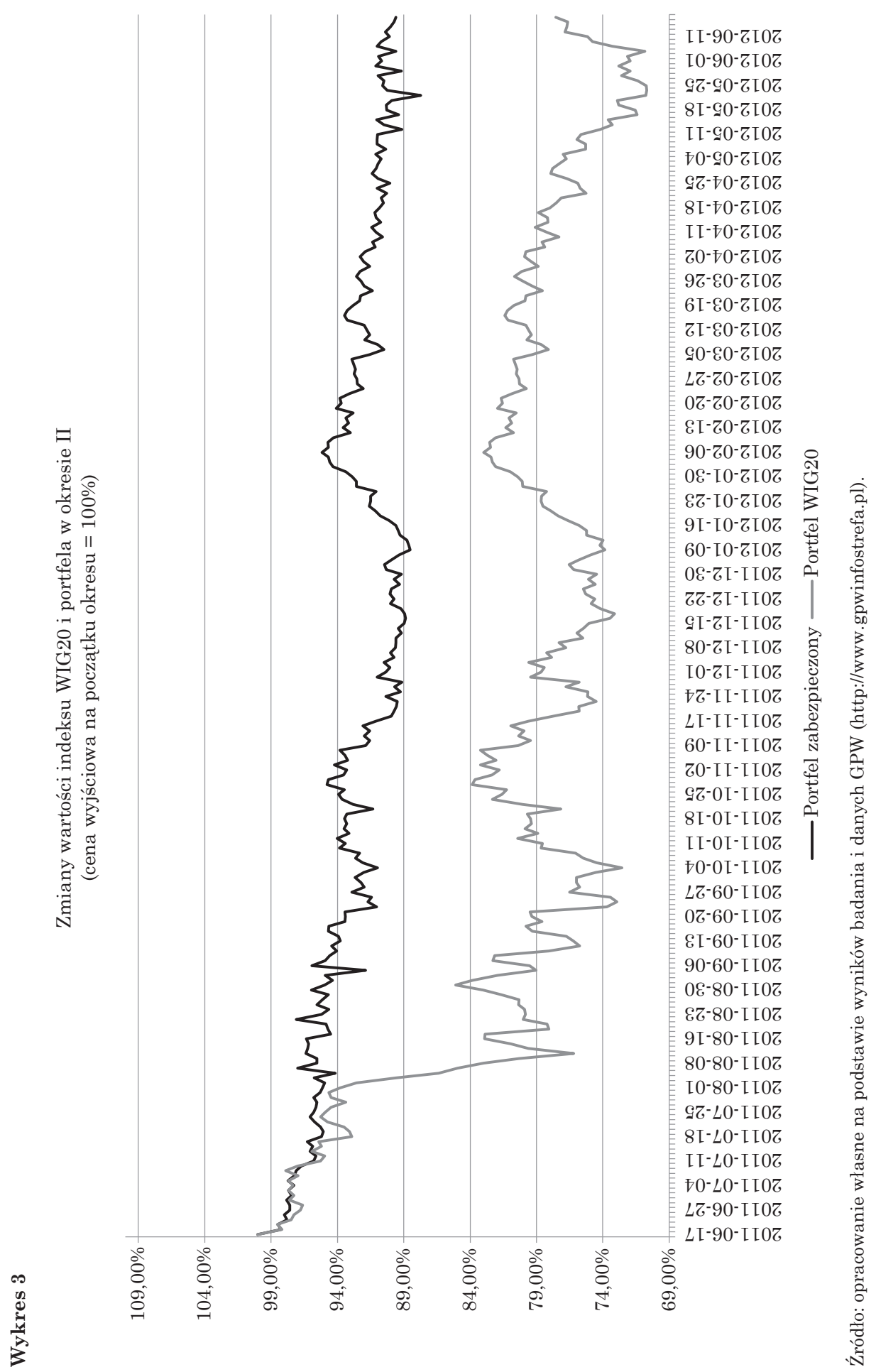




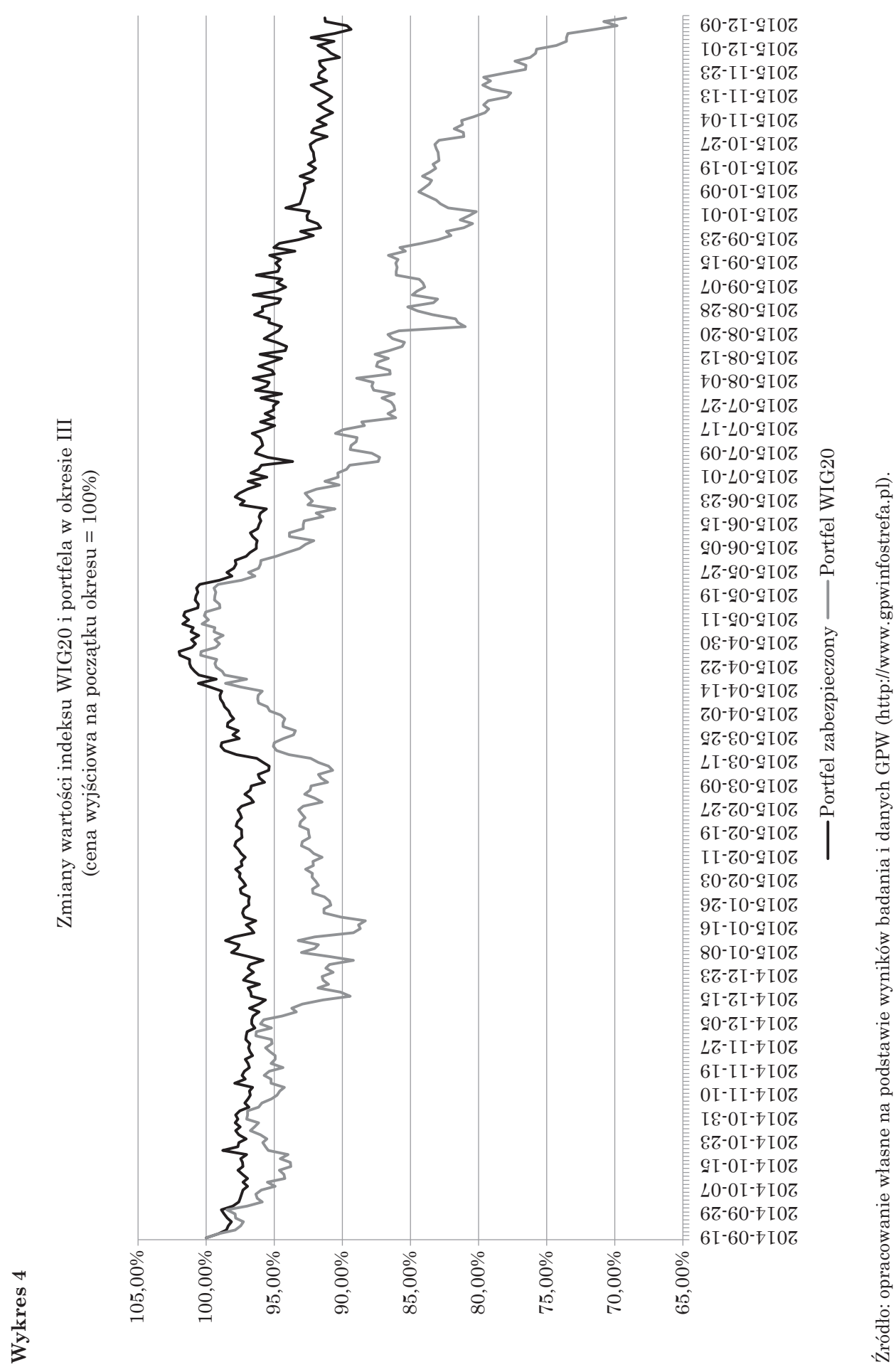




\section{Wykres 5}

Odchylenie standardowe indeksu WIG20 i portfela w okresie I

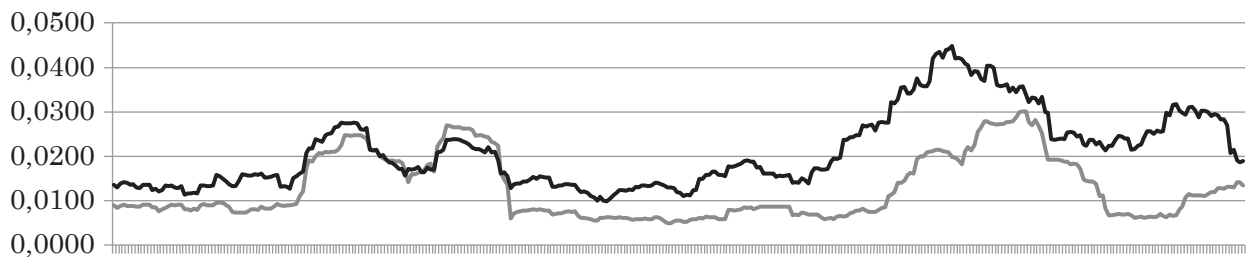
구

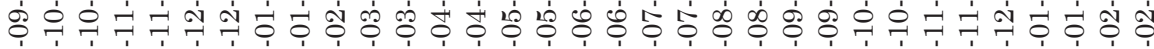

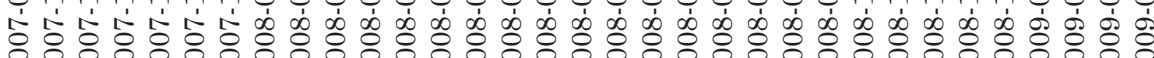

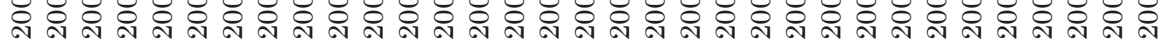

— Portfel zabezpieczony —Portfel WIG20

Źródło: opracowanie własne na podstawie wyników badania i danych GPW (http://www.gpwinfostrefa.pl).

\section{Wykres 6}

Odchylenie standardowe indeksu WIG20 i portfela w okresie II

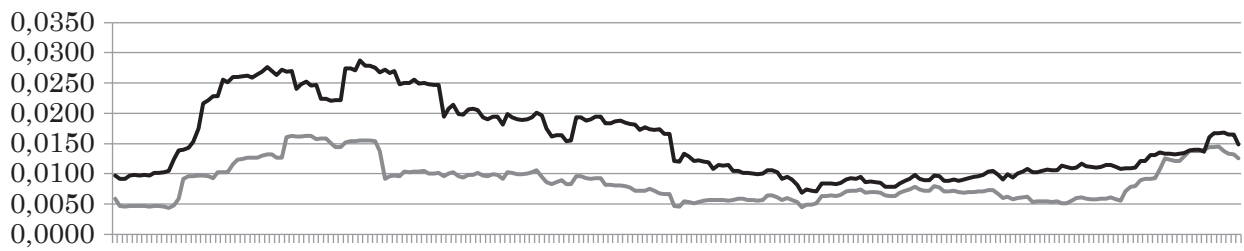

두 ó

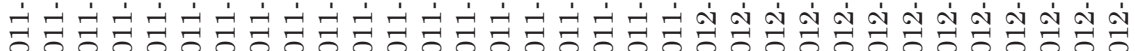

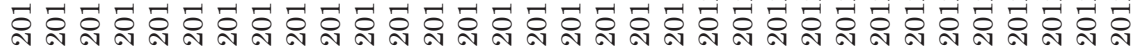

— Portfel zabezpieczony — Portfel WIG20

Źródło: opracowanie własne na podstawie wyników badania i danych GPW (http://www.gpwinfostrefa.pl). 
Wykres 7

Odchylenie standardowe indeksu WIG20 i portfela w okresie III

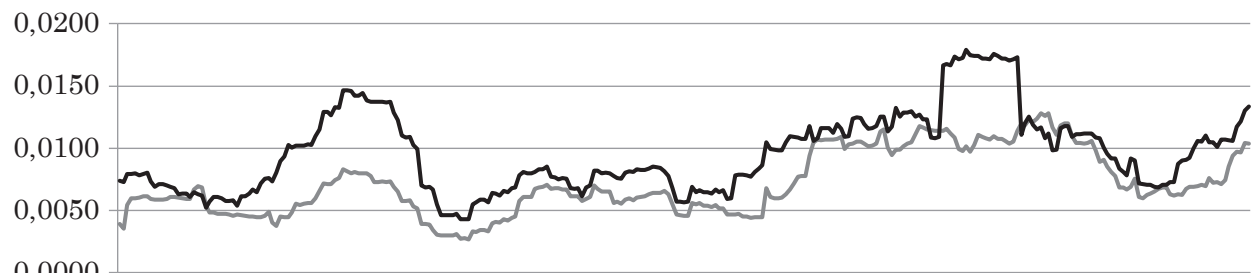

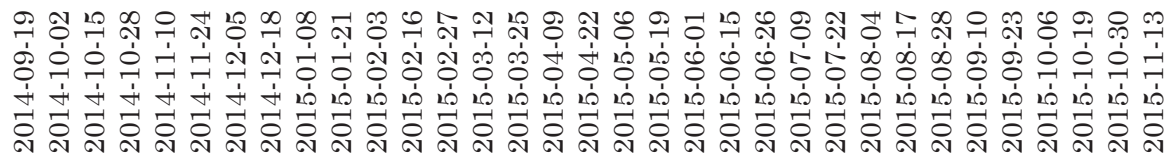

—Portfel zabezpieczony —Portfel WIG20

Źródło: opracowanie własne na podstawie wyników badania i danych GPW (http://www.gpwinfostrefa.pl).

W okresach „rynku byka” indeks WIG20 zazwyczaj zyskiwał więcej. Jednocześnie trzeba zauważyć, że w trakcie korekt tracił on zdecydowanie więcej niż portfel z derywatami, zatem ogólna ocena celowości wykorzystania instrumentów pochodnych musi być pozytywna. Zastosowanie hedgingu wyraźnie poprawiło wyniki inwestycji w okresach badawczych.

Analiza wykresów 5-7 potwierdza wcześniejsze wnioski w kwestii wykorzystania strategii zabezpieczającej. Jego zastosowanie wyraźnie obniżyło obliczone na podstawie „ruchomego okna” 20-sesyjne odchylenie standardowe wartości portfela zabezpieczonego w porównaniu z odchyleniem standardowym wartości WIG20. Miara ta wskazuje, o ile przeciętnie odchylała się stopa zwrotu od średniej. Praktycznie przez wszystkie 3 okresy odchylenie standardowe portfela zabezpieczonego kształtowało się poniżej odchylenia standardowego portfela akcji (indeksu WIG20). We wszystkich okresach zdarzały się dni, dla których 20-sesyjna zmienność była wyższa dla portfela niż dla WIG20. Jednak ogólnie rzecz biorąc, były to sytuacje bardzo rzadkie (kilkanaście dni w całym okresie) i nie wpływają na całościowy obraz. Wykresy w idealny sposób ilustruja, do jak dużego stopnia wykorzystanie hedgingu może być przydatne w celu obniżania ryzyka portfeli. Uogólniając, ryzyko na spadkowym rynku jest znacznie wyższe w przypadku portfeli, których nie zabezpiecza się opcjami indeksowymi. Portfele zabezpieczone opcjami sa bardziej „bezpieczne". Tym samym w pewnych warunkach rynkowych, gdy na rynku utrzymuje się presja podaży lub przewiduje się pogorszenie nastrojów, warto skorzystać z opcji indeksowych. Koszt opcji ATM jest zazwyczaj dość wysoki, ale wydatek na premię opcyjną z pewnością się opłaci, jeżeli przewidywania co do spadku cen okażą się słuszne. 


\section{PODSUMOWANIE}

Na podstawie materiału badawczego wykazano, że portfele zabezpieczone instrumentami pochodnymi cechowały się przeciętnie wyższymi stopami zwrotu i niższym poziomem ryzyka niż portfele stanowiące bazę porównawcza, niezabezpieczone nimi. Wyniki te odzwierciedlone zostały w wartościach mierników efektywności, badających relację pomiędzy ryzykiem i stopą zwrotu. Zdecydowana większość z nich osiaggała korzystniejsze wartości dla portfeli zabezpieczonych. Wskazuje to na wyższą efektywność portfeli wykorzystujących hedging, co świadczy o efektywności strategii znanej w literaturze pod nazwa portfolio insurance. Hipoteza badawcza została zatem zweryfikowana pozytywnie i cel badawczy osiagnięto.

Badanie przeprowadzone w pracy potwierdziło skuteczność zintegrowanego podejścia do inwestowania, tj. jednoczesnego nabycia akcji i instrumentów pochodnych. W przedziale czasowym przyjętym do badania oraz przy uwzględnieniu specyficznych warunków rynkowych i licznych założeń ich wykorzystanie miało korzystny wpływ na efektywność portfeli.

Jednocześnie należy zauważyć, że w innych warunkach rynkowych, np. $\mathrm{w}$ trendzie horyzontalnym lub silnej hossie, wyniki uzyskane w badaniu mogłyby być inne. Zastosowanie derywatów może wpłynać na obniżenie zyskowności portfela w czasie bardzo dobrej koniunktury. Z pewnościa warta przeanalizowania byłaby efektywność portfeli zabezpieczonych w trakcie silnego trendu wzrostowego na rynku. Kolejną istotną kwestią są założenia podjęte w badaniu. Jednym z najważniejszych było zastosowanie opcji ATM. Interesująca kwestią byłaby wrażliwość uzyskanych wyników na zastosowanie innych typów opcji, m.in. OTM i ITM. Należy mieć na uwadze, że wyniki zasadniczo różniłyby się w przypadku hedgingu takimi instrumentami pochodnymi, jak kontrakty futures i forward, opcje egzotyczne, opcje barierowe itd. Ze względu na inne funkcje wypłaty odmiennie kształtowałby się profil zysku całej strategii. Taka sytuacja byłaby szczególnie widoczna w przypadku derywatów symetrycznych. Kolejnym ograniczeniem zakresu badania jest nieuwzględnienie czynników behawioralnych rozumianych jako punkty, w których dokonuje się eksperckich decyzji. Do czynników tych zaliczyć można m.in. dobór rodzajów instrumentów do zabezpieczania wartości portfeli, poszczególnych rodzajów opcji oraz selekcję indeksów i ram czasowych.

Metoda portfolio insurance zaprezentowana $\mathrm{w}$ artykule znajduje zastosowanie m.in. w funduszach hedgingowych. Jednak jej wykorzystanie mogłoby być powszechne w takich instytucjach działających na polskim rynku finansowym, jak domy maklerskie, fundusze inwestycyjne (akcyjne, mieszane, zrównoważonego wzrostu), firmy inwestycyjne, otwarte fundusze emerytalne (OFE) oraz $\mathrm{w}$ przedsiębiorstwach proprietary trading i asset management. Uzupełnienie składu portfeli o derywaty byłoby szczególnie przydatne w portfelach Otwartych Funduszy Emerytalnych działających w Polsce. Ich wykorzystanie zabezpieczyłoby oszczędności przyszłych emerytów i sprawiłoby, że odłożone przez nich środki stałyby się mniej wrażliwe na fluktuacje nastrojów na szerokim rynku oraz zmniejszyłaby się podatność na ryzyko walutowe ak- 
tywów, ulokowanych za granica. Istnieje luka w praktycznym działaniu wymienionych instytucji, która - gdyby została wypełniona - mogłaby się przyczynić do poprawy efektywności zarządzanych przez nie funduszy. Podejście zaprezentowane w badaniu może być wykorzystane w praktyce również przez inwestorów detalicznych tworzących portfele akcji jako strategia inwestycyjna. Ma to polegać na stosowaniu derywatów do zabezpieczania wartości portfela przed gwałtownymi spadkami na giełdzie. Pozwala to także na obniżenie zmienności wartości portfela.

mgr Marcin Flotyński

Uniwersytet Ekonomiczny w Poznaniu

marcin.foltynski@ue.poznan.pl

\section{THE EFFICIENCY OF STOCK PORTFOLIOS HEDGED BY INDEX OPTIONS QUOTED ON THE WARSAW STOCK EXCHANGE}

IN THE YEARS 2007-2015

\section{Sum mary}

In the article quantitative research was conducted on data from the Warsaw Stock Exchange (WSE) for the years 2007-2015. The research focused on an assessment of the success of using derivatives in the context of increasing rates of return and lowering risk. The aim of the article is to check the efficiency of portfolios hedged by index options quoted on the WSE. The time frame was divided into 3 independent periods in order to show the difference in the level of portfolios' efficiency during the bearish trend on the market. In the research quantitative methods have been used, among them comparative analysis and regression analysis to calculate the beta coefficient. The efficiency of hedged portfolios and indices has been measured with the use of the Sharpe ratio, Treynor ratio, Jensen's alpha, Information ratio and Sortino ratio. The hypothesis is formulated that hedged portfolios are more efficient than unhedged ones (stock indexes). The research proved that in the periods given hedged portfolios had by far more favourable level of efficiency measures, so they were more efficient. Their profit to risk ratio was better when index options were included in portfolios. 
